\title{
Correction to: The distribution and chemical coding of enteroendocrine cells in Trypanosoma cruzi-infected individuals with chagasic megacolon
}

\author{
Patrícia Rocha Martins ${ }^{1}$ [D . Josiane Fakhry ${ }^{2}$. Adriana Jacaúna de Oliveira ${ }^{3} \cdot$ Thayse Batista Moreira $^{3}$. \\ Linda J. Fothergill ${ }^{2,5} \cdot$ Enio Chaves de Oliveira ${ }^{4}$. Débora d'Ávila Reis ${ }^{1} \cdot J^{2}{ }^{3} \cdot$ B. Furness ${ }^{2,5}$
}

Published online: 15 February 2021

(c) Springer-Verlag GmbH Germany, part of Springer Nature 2021

\section{Correction to: Histochemistry and Cell Biology https://doi.org/10.1007/s00418-020-01947-w}

In the original publication of the article, order of the affiliations was published with an error.

The correct affiliations are given in this correction.

The original article has been updated.

${ }^{1}$ Instituto de Ciências Biológicas, Universidade Federal de Minas Gerais, Belo Horizonte, MG, Brazil

${ }^{2}$ Department of Anatomy \& Neuroscience, University of Melbourne, Parkville, Victoria 3010, Australia
${ }^{3}$ Mário Penna Institute, Center for Teaching and Research, Belo Horizonte, MG, Brazil

${ }^{4}$ Universidade Federal de Goiás, Goiânia, GO, Brazil

${ }^{5}$ Florey Institute of Neuroscience and Mental Health, Parkville, Victoria 3010, Australia

Publisher's Note Springer Nature remains neutral with regard to jurisdictional claims in published maps and institutional affiliations.

The original article can be found online at https://doi.org/10.1007/ s00418-020-01947-w.

\footnotetext{
Patrícia Rocha Martins

pmbiocel@gmail.com

1 Instituto de Ciências Biológicas, Universidade Federal de Minas Gerais, Belo Horizonte, MG, Brazil

2 Department of Anatomy \& Neuroscience, University of Melbourne, Parkville, Victoria 3010, Australia

3 Mário Penna Institute, Center for Teaching and Research, Belo Horizonte, MG, Brazil

4 Universidade Federal de Goiás, Goiânia, GO, Brazil

5 Florey Institute of Neuroscience and Mental Health, Parkville, Victoria 3010, Australia
} 